\title{
High-Speed Railways is a Priority Direction for the Development of Railway Transport
}

\author{
Viktoriia Yanovska ${ }^{1}$, Olga Levchenko $^{2}$, Viktoriia Tvoronovych $^{3}$, and Anastasiia Bozhok $^{41}$ \\ ${ }^{1}$ State University of Infrastructure and Technologies, Head of the department "Economics, marketing \\ and business administration", Kyrylivska str, 9. Kyiv, 02000, Ukraine \\ ${ }^{2}$ State University of Infrastructure and Technologies, associate professor of the department \\ "Economics, marketing and business administration", Kyrylivska str, 9. Kyiv, 02000, Ukraine. \\ ${ }^{3}$ State University of Infrastructure and Technologies, associate professor of the department \\ "Economics, marketing and business administration", Kyrylivska str, 9. Kyiv, 02000, Ukraine \\ ${ }^{4}$ State University of Infrastructure and Technologies, associate professor of the department \\ "Economics, marketing and business administration", Kyrylivska str, 9. Kyiv, 02000, Ukraine
}

\begin{abstract}
The article deals with the Chinese global strategy the Silk Road Economic Belt and the possibility of involving Ukraine in it. The authors pay special attention to the implementation of the China-UkraineEU High-Speed Railway Project within the framework of the Silk Road Strategy. The geopolitical position of Ukraine allows the authors to state that Ukraine may represent a special interest for the Celestial Empire as a logistical hub and a kind of "window" to Europe, as the central axis of the international transport corridors passes through Ukraine. The authors analyze the direct economic, as well as external economic and social effects of the construction of High-Speed Railways in Ukraine.
\end{abstract}

\section{Introduction}

China is the world leader in the production and export of most types of products. Its foreign policy is aimed at expanding the resource base and markets of the Chinese products [1]. With its flexibility and pragmatism, China established itself as a regional leader, consolidating the sphere of influence in the Southeastern and Central Asia. Due to the globalization of foreign trade and policies, PRC has expanded the range of its economic partners in Africa and Latin America. At the same time, China seeks to expand the geography of economic cooperation at the expense of EU countries. In this regard, Central and Eastern European (CEE) countries play an important role, which may be a perfect basis for a common EU market, as well as by convergence with the countries of the region China seeks to lobby for its interests at the EU level and to determine the agenda for cooperation between China and EU [2].

In this regard, in 2013, the Chinese President Xi Jinping announced the Silk Road Economic Belt Project as a new form of deepening cooperation between China, the states of Central Asia, Russia and Europe. The Silk Road Economic Belt Project provides a new

\footnotetext{
${ }^{1}$ Corresponding author: nastya.bozhok@gmail.com
} 
model of regional cooperation based on an innovative idea, which connects the Silk Road and the Economic Belt. The Silk Road Economic Belt is considered not only as a transit transport project and a direction for accelerating the development of the western regions of China and Eurasia, but also as a strategy for the economic development of a number of countries, which includes infrastructure development, industry, trade and services [3].

The Great Silk Road provides several routes from the western regions of the People's Republic of China towards the key centers of economic activity in Europe and South Asia, covering from 8.5 to 11 thousand $\mathrm{km}$. It is assumed that the North route will pass through the territory of Kazakhstan and the Trans-Siberian Railway. The sea routes will be operated by the Kazakh port of Aktau, as well as ports in the Caspian Sea (Makhachkala, Baku) providing access to the Caucasus region, Turkey and the Black Sea basin. The southern routes run along Kyrgyzstan, Uzbekistan, Turkmenistan, Iran and Pakistan, providing access to the Indian Ocean in the Arabian Gulf region [4].

\section{Ukraine's Place in China's Global Strategies}

Involving Ukraine in these projects will allow us to build the shortest link between the Eastern Asian and European countries, as well as significantly reduce the delivery and storage times. The Eurasian direction of economic interest for Ukraine and distinguish the economic corridors of the New Silk Road which are worth noticing include China-Pakistan corridor; Bangladesh-China-India-Myanmar Corridor; Indochina Peninsula Corridor; New Eurasian Land Bridge; China-Mongolia-Russia Corridor. For Ukraine, it is in particular China - Central Asia - West Asia corridor, through Turkey, the South Caucasus, and the countries of Central Asia [5].

The construction of the transcontinental railway is of strategic importance for the development of the transport industry of Ukraine, as it involves the construction of new international highways, the creation of infrastructure objects, including transport and logistics complexes, construction of high-speed railways, which allow reaching a speed mode of more than $200 \mathrm{~km} / \mathrm{h}$.

Ukraine can represent a special interest in the Celestial Empire as a logistical hub and a kind of "window" to Europe, as the central axis of international transport corridors passes through Ukraine, which include the main railway routes that can become part of the Ukrainian section of the Lisbon- Shanghai Railway:

1) Zernove (border with Russia) / Hornostaivka (border with Belarus) - Nizhyn - Kyiv - Zhmerynka - Kuchurhan (border with Moldova) / Odessa. The length of the route is 1159 $\mathrm{km}$;

2) Chop (border with Slovakia and Hungary) / Mostynska 2 (border with Poland) - Lviv - Zhmerynka - Fastiv - Dnipro - Krasnoarmiysk - Debaltseve - Chervona Mohyla (border with Russia) / Yasynuvata - Kvashyno (border with the Russian Federation). The length of the route is $1792 \mathrm{~km}$; and

3) Izov / Yagodyn (border with Poland - Kovel -Zdolbunov - Shepetovka - Kozyatin Kyiv - Poltava - Kharkiv - Kupiansk - Topoli). The length of the route is $1167 \mathrm{~km}$ [6].

Thus, Ukraine can become a full member of the corridor with a potential of 10 million tons of cargo per year. At the same time, the Ukrainian-Chinese bilateral trade has great prospects, under the condition of effective foreign economic policy and rational use of the resource potential of bilateral cooperation. This is confirmed by the data of the State Statistics Service of Ukraine in the geographical structure of the foreign trade turnover between Ukraine and the countries that are part of the Caspian-Black Sea route of the New Silk Road: in 2017 from the PRC - \$7,688 million, Poland - \$6,039.4 million, Germany $\$ 5,529.1$ million [7]. At the same time, interstate trade between Ukraine and China is asymmetric: China is the third trading partner of Ukraine (after the EU and Russia), while 
Ukraine is only the third partner in the post-Soviet space (after Russia and Kazakhstan). Due to the agrarian sector, Ukraine became one of the leaders among exporters of food products to the Celestial Empire [2].

Ukraine can be of particular interest to China as a large-scale logistics center, because its territory is the central axis of the international transport corridors. During 2008-2018, the volume of trade between Europe and China increased by almost 50\% (Fig. 1), which confirms the necessity of construction of High-Speed Railways through Ukraine in order to accelerate trade between the EU and China.

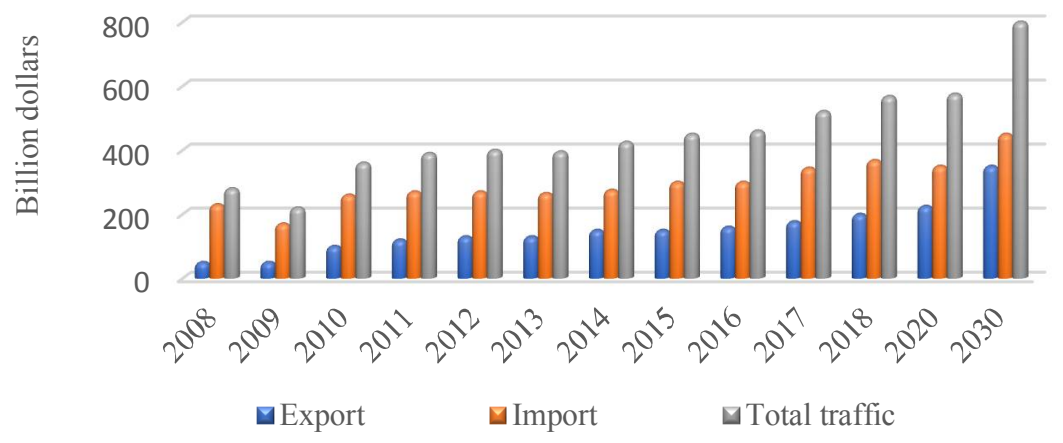

Fig. 1. EU-China Trade Turnover $[8,9]$.

\section{Potential benefits from the implementation of high-speed railway projects in Ukraine}

Ukraine has the opportunity to effectively use its geographic potential, which is capable of accelerating the trade between the EU and China. To this end, it initiated an international project "High-Speed Railways - 1435". It is proposed to build a High-Speed Railways through Ukraine from China to Europe. The railway will connect the Celestial Empire with 7 states - Kazakhstan, Uzbekistan, Turkmenistan, Azerbaijan, Georgia, Ukraine, and Poland. The total length of the railway corridor will be $5100 \mathrm{~km}$ (excluding sea distances), which is 200 kilometers shorter than the Eurasian Land Bridge (China - Kazakhstan Russia - Belarus - Poland), which now passes containers from China to the European Union. These $200 \mathrm{~km}$ will save 4.5 billion dollars, at an average cost of $1 \mathrm{~km}$ of HighSpeed Railway 21 million dollars. [2]. It is important to note that today the main flow of goods between the leading commodity markets of the world - China and the EU countries is carried by sea for 30-40 days, as well as by the Trans-Siberian Railway from China to Russia, Belarus, Poland in small but growing volumes of transportation. Therefore, the implementation of the High-Speed Railways project will significantly accelerate the delivery of goods.

Ukraine-China strategic partnership as a kind of bilateral relations is of a profound nature, which is not limited only to foreign trade relations and financial benefits, the influence on different socio-economic processes should also be taken into account:

1) Modernization of infrastructure (ports, motorways, railways) at the expense of the Chinese capital;

2) Additional component of the European integration of Ukraine;

3) Strengthening of the regional position of Ukraine in the CEE;

4) Reduction of pressure from Russia due to the inclusive and mutually beneficial nature of cooperation of all interested parties; 
5) During 10 years of operation of the high-speed railway "1435", an increase in transit traffic of goods will be at least 18 million tons a year, in the context of a significant improvement in the quality performance indicators: two - three times the average speed growth, multiple reduction of downtime;

6) 450 thousand new jobs will be created during the construction phase, and at the exploitation stage - 70 thousand. And these are only direct effects. Thanks to the project, new jobs will be created in other sectors of the economy. In addition, the requirements for the quality of labor force, level of its qualification and professional education will be raised; 7) The high-tech production will be developing. As a result of the fact that the creation and operation of the high-speed railway "1435" is not a one-time measure and in the process of functioning of a new industry it cannot be limited to the purchase of several rolling stock, and technology transfer will take place. Obtaining access by the Ukrainian producers to world technologies will make it possible to create a market for own competitive products with high added value;

8) In the process of construction and operation of High-Speed Railway "1435" the largescale orders of products, works and services will take place. Accordingly, the industry, the construction industry, the sphere of services, education, and science will be developing;

9) Expected growth of the industrial production during construction for 2 trillion hryvnias, for ten years of operation - 30 trillion hryvnias;

10) High-Speed Railways will play a significant role in the growth of the socio-economic level of the regions, especially the railway areas, namely, Kyiv, Odessa, Vinnytsia, Khmelnytskyi, Ternopil and Lviv regions, whose gross regional product, due to the construction of transport hubs, the creation of logistics terminals, the growth of economic activity of the population, will increase by $10 \%$ per year, and its growth will exceed UAH 800 billion for ten years of its exploitation; and

11) Extra tax revenues only from the freight traffic will be almost 80 billion UAH for ten years of operation of 1435 railways. In addition, additional tax revenues from high-speed passenger transportation, the growth of industrial production, the development of services, education, science, increase in the economic activity of the population in the regions [10].

Thus, the implementation of the High-Speed Railway 1435 Project, with the corresponding creation of a new industry and new productions, is oriented and objectively determines the socio-economic development of Ukraine and is very important in the modern conditions. The need for economic growth, integration into the global economic system requires accelerated development of the transport complex of the country. It is necessary to support the importance of Ukraine as a transit state, the Ukrainian manufacturer with new orders, the labor market and create conditions for the growth of the welfare of the population.

\section{Silk Road Program and Financing}

The development program of the "Silk Road Economic Belt" project consists of the following items:

1) Intergovernmental cooperation, strengthening coordination of the states of the region in the political sphere;

2) Infrastructure integration, intensification of construction of a unified road network;

3) Development and reduction of trade expenses by eliminating trade barriers, increasing the speed and quality of the economic operations;

4) Financial integration, that is, an increase in foreign exchange flows through the transition to payments in the national currencies; and 
5) Strengthening the role of international diplomacy, scientific and cultural exchanges, tourism, health care, etc.

It should be noted that more than 30 countries have entered into agreements on joining the project "One Belt - One Way".

China is cooperating in the construction of individual industrial projects with more than 20 countries. It is supposed to provide financial support to China from the countries participating in this project. New institutions have been created: the Silk Road Fund, the Asian Infrastructure Investment Bank. The Silk Road Fund is made up of the Chinese funds (based on foreign exchange reserves, Chinese Investment Company, Chinese Import and Export Bank, State Development Bank of China) that will be used to build the Silk Road Economic Belt. Also, the PRC will provide support for training 20,000 professionals for five years to work on the implementation of the strategy.

The infrastructure is the primary and most cost-effective part of the project implementation. The Great Silk Road provides several routes from the western regions of the People's Republic of China towards the key centers of economic activity in Europe and South Asia, covering from 8.5 to 11 thousand $\mathrm{km}$. It is assumed that the North route will pass through the territory of Kazakhstan and the Trans-Siberian Railway. The sea routes will be operated by the Kazakh port of Aktau, as well as ports in the Caspian Sea (Makhachkala, Baku) providing access to the Caucasus region, Turkey and the Black Sea basin.

The southern routes run along Kyrgyzstan, Uzbekistan, Turkmenistan, Iran and Pakistan, providing access to the Indian Ocean in the Arabian Gulf region [4].

\section{Conclusion}

It should be noted that in the external environment there may be certain circumstances that would impede the implementation of the Silk Road project, in particular the application of the political considerations in economic logic in the field of transport and transit of goods and energy; strict national requirements for the transportation of goods, which are the cause of slowing cargo flows; lack of necessary financial resources from the countries to implement large-scale projects; lack of security in some areas and their borders (Afghanistan, the Caucasus, Ukraine), which is the reason that some routes are not used.

However, the deepening of the Ukrainian-Chinese cooperation and the construction of the high-speed Ukraine-China-EU will create many opportunities, there are a significant acceleration of trade turnover, modernization of infrastructure (ports, roads, railways); and strengthening the regional position of Ukraine in the CEE among the largest ones. In addition, infrastructure-related projects are essentially development-oriented. Therefore, their implementation leads to the expansion of orders to enterprises in different industries, job creation, increase in household incomes, expansion of domestic consumption, payment of taxes, increase in budget revenues, as well as the appearance of many other effects.

\section{References}

1. Eurostat Statistics [online], Available at: https://ec.europa.eu/eurostat/statisticsexplained/index.php/China-EU_-_international_trade_in_goods_statistics.

2. Ukraine's place in the China's global strategies. International Centre for Policy Studies. 5-22 (2015).

3. M. Shevchenko. From China to Ukraine: New Silk Road. Unian [online], Available at: http://economics.unian.net/finance/1552361-izkitaya-v-ukrainu-novyiy-shelkovyiy put.html.

4. V. Povoroznik, V. Perebyinis. International Centre for Policy Studies. 31. (2015). 
5. I. Shevyrev. Three years of Silk Road. Political news [online], Available at: http://izvestia.kiev.ua/blog/show/84135\#disqus thread.

6. V.L. Dykan. The economic zone of the Silk Road in the context of the strategic priorities of Ukraine's economic development. International transport corridors and corporate logistics. 6-7 (2015).

7. External economic activity. State statistics Service of Ukraine [online], Available at: http://www.ukrstat.gov.ua.the

8. World Trade Organization: world trade statistical review [online], Available at: https://data.wto.org/.

9. V. Yanovska, O. Pylypenko, V. Tvoronovych, A. Bozhok. . International Journal of Engineering \& Technology, 7 (4.3), 583-587 (2018).

10. Project concept high speed lines «China-Ukraine-EU». Materials of the Raund table of Association High-Speed Highways. 2018 p. 